https://doi.org/10.15407/ujpe65.8.686

V. SMOKAL,${ }^{1}$ O. KHARCHENKO, ${ }^{1}$ O. KRUPKA,${ }^{1}$ S. STUDZINSKY,${ }^{1}$ N. DAVIDENKO,${ }^{1}$ V. FIGÀ ${ }^{2}$

1 Taras Shevchenko National University of Kyiv

(60, Volodymyrs'ka Str., Kyiv 01033, Ukraine; e-mail: vitaliismokal@gmail.com)

2 Euro-Mediterranean Institute of Science and Technology (IEMEST)

(20, Michele Miraglia Via., Palermo 90139, Italy)

\title{
CHANGES IN OPTICAL PROPERTIES OF AZOPOLYMERS IN AN ELECTRIC FIELD
}

\begin{abstract}
We report the preliminary results obtained for polymers incorporating the azobenzene sidegroup as an optically active molecule. The reversible change of the thin film absorption is observed when illuminating it with monochromatic linearly polarized light under the applied external DC field. The magnotude of a change depends on the angle between the light polarization and the DC electric field direction.
\end{abstract}

Keywords: polymers, aryl(meth)acrylates, electrooptical effect, azobenzene dyes, optical properties.

\section{Introduction}

Polymers containing chromophore molecules have been extensively studied by many research groups due to their promising photonic applications to the optical data storage, surface-relief holography, optical switching, etc. [1-8]. The desirable properties of azobenzene materials are attributed to the highly efficient photo-reversable trans-cis isomerization of azobenzene moieties [9-11]. Generally, this phenomenon is induced by the light with frequencies above the onehalf of the main resonance of a material [12], and its efficiency is resonantly enhanced via the one-photon absorption.

The polar orientation of chromophores can be done by applying an external electric DC field. The orienting force originates from the interaction of molecule dipole moments with the applied external electric field, which tends to orient them in its direction [13]. Therefore, molecules with large dipole moments are needed. An example of such molecules presents intramolecular charge transfer (CT) ones with electrondonating and electron-accepting groups. The $(\pi)$ electron conjugated azobenzene moiety, linking a donor with an acceptor, serves as a charge transmitter between them. Such molecules lack also the center of inversion, a property necessary to obtain the third- and

(c) V. SMOKAL, O. KHARCHENKO, O. KRUPKA, S. STUDZINSKY, N. DAVIDENKO, V. FIGÀ, 2020 second-order NLO effects [14-16] such as the third harmonic generation (THG), second harmonic generation (SHG), and linear electro-optical effect. This fact is important for a proper choice of compounds designed for the application in optoelectronic devices. In this paper, we report on the synthesis of side chain polymers with azobenzenes. The linear electro-optical effect in thin films will be reported and discussed.

\section{Instruments for Characterization}

${ }^{1} \mathrm{H}$ NMR (500 MHz) spectra were recorded by a "Bruker Advance DRX-500" spectrometer. Chemical shifts are in ppm from the internal standard tetramethylsilane. UV-VIS measurements were performed at room temperature either in solutions in a quartz liquid cell, with a Perkin-Elmer UV/VIS/NIR Lambda 19 spectrometer. Differential Scanning Calorimetry: A Q20 model DSC (TA Instruments) with a continuous $\mathrm{N}_{2}$ purge was used to determine the glass and phase transition temperatures $\left(T_{g}\right)$ of all polymers. Two scans were run at a heating rate of $10{ }^{\circ} \mathrm{C} / \mathrm{min}$ up to $200{ }^{\circ} \mathrm{C}$, followed by a cooling to $20^{\circ} \mathrm{C}$, giving the values of $T_{g}$.

\section{Materials Synthesis}

$2,2^{\prime}$-Azobis(isobutyronitrile) (AIBN) was recrystallized twice from methanol. Methacrylic chloride was vacuum distilled, immediately before the use. Me-

ISSN 2071-0194. Ukr. J. Phys. 2020. Vol. 65, No. 8 
thylmethacrylate (MMA) was washed with aq $\mathrm{NaOH}$ to remove inhibitors and dried with $\mathrm{CaCl}_{2}$ under nitrogen at a reduced pressure. The chromophores were purchased from Aldrich and purified by the double recrystallization from a methanol solution. All other reagents and solvents were commercially available and used as-received. Azomonomer was synthesized in the same way as reported [17].

\section{4-(N-Ethyl-N-(2-hydroxyethyl)amino)- 4'-(4-nitrophenylazo)azobenzene}

The dark purple crystals m.p. $225{ }^{\circ} \mathrm{C}, 62 \% .{ }^{1} \mathrm{H}$ NMR (500 MHz, DMSO-d6): $8.46(d, 2 \mathrm{H}, \mathrm{Ar}-\mathrm{H}), 8.00(d$, $2 \mathrm{H}, \mathrm{Ar}-\mathrm{H}), 8.12(d, 4 \mathrm{H}, \mathrm{Ar}-\mathrm{H}), 7.85(d, 2 \mathrm{H}, \mathrm{Ar}-$ $\mathrm{H}), 6.90(d, 2 \mathrm{H}, \mathrm{Ar}-\mathrm{H}), 4.85(t, 1 \mathrm{H}, \mathrm{OH}), 3.55-3.65$ $\left(m, 6 \mathrm{H},-\mathrm{CH}_{2}-\right), 1.18\left(s, 3 \mathrm{H},-\mathrm{CH}_{3}\right)$. UV-VIS (THF): $(\lambda)=346,520 \mathrm{~nm}$.

4-((2-Methacryloyloxyethyl)ethylamino)4-nitroazobenzene (M1)

Dark red crystals m.p. $83{ }^{\circ} \mathrm{C}$, yield $80 \% .{ }^{1} \mathrm{H}$ NMR $\left.\left(500 \mathrm{MHz} \mathrm{CDCl}_{3}\right): 8.35 d, 2 \mathrm{H}, \mathrm{Ar}-\mathrm{H}\right), 7.92(t, 4 \mathrm{H}$, $\mathrm{Ar}-\mathrm{H}), 6.85(d, 2 \mathrm{H}, \mathrm{Ar}-\mathrm{H}), 6.1\left(s, 1 \mathrm{H}, \mathrm{CH}_{2}\right), 5.6(s$, $\left.1 \mathrm{H}, \mathrm{CH}_{2}\right), 4.38\left(m, 2 \mathrm{H}, \mathrm{OCH}_{2}\right), 3.75\left(m, 2 \mathrm{H}, \mathrm{NCH}_{2}\right)$, $3.56\left(m, 2 \mathrm{H}, \mathrm{NCH}_{2}\right), 1.94\left(s, 3 \mathrm{H}, \mathrm{CH}_{3}\right), 1.24(m, 3 \mathrm{H}$, $\mathrm{CH}_{3}$ ). UV-VIS (THF): $(\lambda)=475 \mathrm{~nm}$.

4-((2-Methacryloyloxyethyl)ethylamino)-

4'-(4-nitrophenylazo)azobenzene (M2)

Dark purple crystals; yield $60 \%$; m.p. $160{ }^{\circ} \mathrm{C} .{ }^{1} \mathrm{H}$ NMR $\left(500 \mathrm{MHz}, \mathrm{CDCl}_{3}\right): 8.40(d, 2 \mathrm{H}, \mathrm{Ar}-\mathrm{H}), 8.12-$ $7.92(m, 8 \mathrm{H}, \mathrm{Ar}-\mathrm{H}), 6.85(d, 2 \mathrm{H}, \mathrm{Ar}-\mathrm{H}), 6.12(s, 1 \mathrm{H}$, $\left.\mathrm{CH}_{2}\right), 5.61\left(s, 1 \mathrm{H}, \mathrm{CH}{ }_{2}\right), 4.38\left(t, 2 \mathrm{H}, \mathrm{OCH}_{2}\right), 3.75$ $\left(t, 2 \mathrm{H}, \mathrm{NCH}_{2}\right), 3.55\left(q, 2 \mathrm{H}, \mathrm{NCH}_{2} \mathrm{CH}_{3}\right), 1.97(s, 3 \mathrm{H}$, $\left.\mathrm{CH}_{3}\right), 1.28\left(s, 3 \mathrm{H}, \mathrm{CH}_{3}\right)$. UV-VIS (THF): $(\lambda)=340$, $502 \mathrm{~nm}$.

\section{$4^{\prime}$-[(2-Methacryloyloxyethyl)ethylamino]-} 4-cyanoazobenzene (M3)

Red solid residue, yield: 87\%. ${ }^{1} \mathrm{H}$ NMR (500 MHz, $\left.\mathrm{CDCl}_{3}\right): 7.89,7.87(d, 4 \mathrm{H}, \mathrm{Ar}-\mathrm{H}), 7.75,7.73(d, 2 \mathrm{H}$, $\mathrm{Ar}-\mathrm{H}), 6.82,6.8(d, 2 \mathrm{H}, \mathrm{Ar}-\mathrm{H}), 6.1\left(s, 1 \mathrm{H}, \mathrm{CH}_{2}\right)$, $5.6\left(s, 1 \mathrm{H}, \mathrm{CH}_{2}\right), 4.36\left(m, 2 \mathrm{H}, \mathrm{OCH}_{2}\right), 3.7(m, 2 \mathrm{H}$, $\left.\mathrm{NCH}_{2}\right), 3.55\left(m, 2 \mathrm{H}, \mathrm{NCH}_{2}\right), 1.94\left(s, 3 \mathrm{H}, \mathrm{CH}_{3}\right), 1.25$ $\left(m, 3 \mathrm{H}, \mathrm{CH}_{3}\right)$. UV-VIS (THF): $(\lambda)=250,450 \mathrm{~nm}$.

\section{Polymerization and Thin Films Processing}

Polymers were synthesized by the free-radical polymerization (see Fig. 1). The polymerization was car-

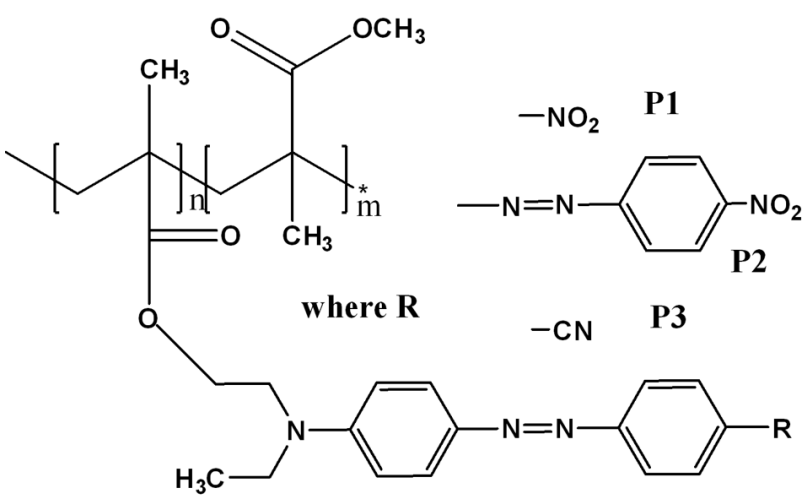

Fig. 1. Polymers under study

ried out in a $10 \mathrm{wt} \%$ toluene solution of $\mathrm{M} 1$ and methylmethacrylate (MMA) with the initial mole ratio of monomers $1: 3$. The polymerization was conducted using AIBN as a free radical initiator (1 wt\% of monomer) at $80{ }^{\circ} \mathrm{C} 35 \mathrm{~h}$ in the argon atmosphere. Previously, the initial mixture was degassed with repeated freeze-pump-taw cycles. The polymerization was stopped by pouring the reaction mixture into methanol. This procedure was repeated several times to ensure the removal of unreacted methacrylic monomers. Finally, polymer P1 was dried under vacuum at $50{ }^{\circ} \mathrm{C}$ overnight. In the cases of copolymerization M2 with MMA and M3 with MMA, the same synthetic procedure was used in DMF, 1,4-dioxane, and toluene solutions, respectively. The copolymerization ratios of units in the corresponding polymers were calculated on the basis of the integrated peak areas of ${ }^{1} \mathrm{H}$ NMR spectra. The glass transition temperatures have been measured by differential scanning calorimetry to be $125{ }^{\circ} \mathrm{C}, 140{ }^{\circ} \mathrm{C}$, and $120{ }^{\circ} \mathrm{C}$ for copolymers $\mathrm{P} 1, \mathrm{P} 2$, and $\mathrm{P} 3$, respectively. Thin films of P1, P2, and P3 were obtained by the drop casting of filtered solutions through a $0.4 \mu \mathrm{m}$ pore size nylon syringe filter on a conducting layer $\mathrm{SnO}_{2}: \mathrm{In}_{2} \mathrm{O}_{3}$ of glass slides. As a solvent, we used dichlororethane for the quality of thin film formation. The same polymer concentration of $56 \mathrm{~g} / \mathrm{l}$ was used. Immediately after the deposition, the films were cured in a vacuum drying chamber at $50{ }^{\circ} \mathrm{C}$ for $180 \mathrm{~min}$ in order to eliminate any remaining solvent.

\section{Experimental}

Spectra of optical density $(D)$ of the studied films over the interval of light wavelengths $\lambda=350-900 \mathrm{~nm}$ 


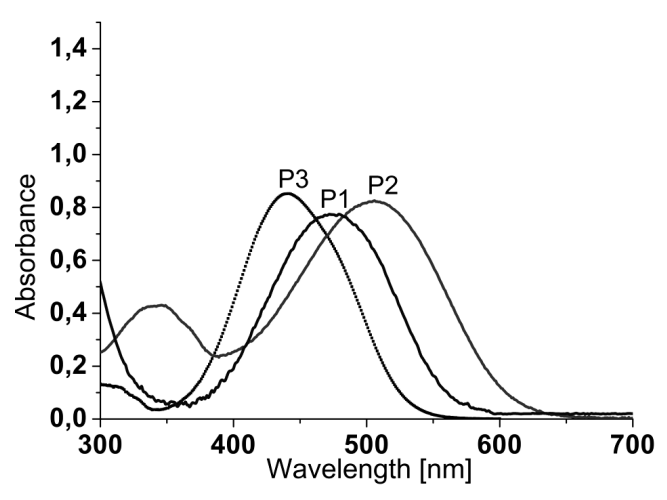

Fig. 2. The absorption spectra of $\mathrm{P} 1-\mathrm{P} 3$ in $\mathrm{THF}$

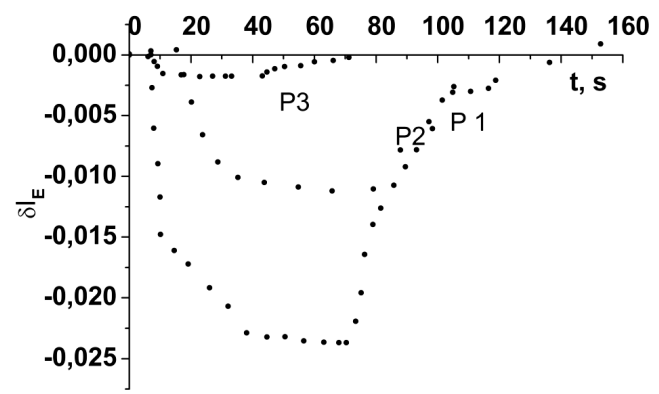

Fig. 3. Dependences of $\delta I_{E}$ on the time $t$ after the application of an external electric field and its switching-off after 50-60 s measured for $\theta=\pi / 2$ and $\lambda=610 \mathrm{~nm}$ in the samples with films of P1-P3. The samples were preliminarily illuminated with linearly polarized light $(\lambda<550 \mathrm{~nm})$ for $60 \mathrm{~min}$



Fig. 4. Dependences of $\delta I_{E}$ on $\lambda$ measured for $\theta=\pi / 2$ in the samples with P1 (1), P2 (2), P3 (3), after their previous illumination with linearly polarized light $<550 \mathrm{~nm}$ for $60 \mathrm{~min}$

were measured in these samples, as well as the value $\delta I_{E}=\left(I_{E}-I_{0}\right) / I_{0}$, where the intensities of monochromatic light passed through the sample before $\left(I_{0}\right)$ and after $\left(I_{E}\right)$ the application of the external electric field. Unpolarized, as well as polarized, light was used for the illumination of samples. In the second case, a sample was placed between two polarizers. The elec- tric field $E=1 \times 10^{8} \mathrm{~V} / \mathrm{m}$ in the studied films was produced by a corona discharge in a special device. The dependences of $\delta I_{E}$ on the time $t$ of the sample illumination, time after the illumination, light wavelength $\lambda$ corresponding to the long-wave edge of the absorption of polymer films, and angle $\theta$ between the axes of a polarizer and an analyzer were measured. All experiments were carried out at the temperature $T=293 \mathrm{~K}$ when the depolarizing influence of the $\mathrm{SnO}_{2}: \mathrm{In}_{2} \mathrm{O}_{3}$ layer is negligible [18].

\section{Results and Discussion}

4-(N-ethyl-N-(2-hydroxyethyl)amino)-4-cyanoazobenzene and 4-(N-ethyl-N-(2-hydroxyethyl)amino)4'-(4-nitrophenylazo)azobenzene were prepared by coupling the diazonium salt of 4 -aminobenzonitrile or 4-(4-nitrophenylazo)aniline correspondingly with 2-( $N$-ethylanilino)ethanol according to the procedure published previously [19]. The polymers were synthesized by the radical polymerization using AIBN as a radical initiator.

The absorption spectra of the investigated polymer films are shown in Fig. 2. Over the visible range, the absorption is conditioned by the photoexcitation of azobenzene chromophore groups, notably the intense band assigned to the vibronic coupling between $n-\pi^{*}$ and $\pi-\pi^{*}$ electronic transitions of azobenzene polymers. The bathochromic shift observed in the series of P1-P3 polymers is caused by an increase of the chromophore dipole moment. The electron-donor and electron-acceptor substituents in the synthesized polymers increase the charge transfer character of the $\pi-\pi^{*}$ transition and consequently a red shift of the $\pi-\pi^{*}$ band. Therefore, changing the strength of electrondonor and electron-acceptor substituents leads to a lowering of the energy of excited states.

The intensity of polarized light passing the samples with the investigated polymer film preliminarily illuminated by a linearly polarized light decreases (Fig. 2) after the application of an external electric field. It returns to its initial value, when the electric field is switched-off. It is well known from the studies done at room temperature for polymers similar to the presently investigated ones that the transstate of azobenzene chromophore groups is predominant before the illumination with linearly polarized light. The illumination with linearly polarized light of these polymers induces a polarization which is due to the population changes of trans- and cis- 
isomers of the azobenzene groups. The induced orientations of the electric dipole moments of trans- and cis-isomers of the azobenzene chromophores do not coincide. Therefore, the modification of the absorption of polarized light by isomers of azobenzene chromophores in polymers, when an external electric field is applied, (Fig. 4) is caused by a rotation of the electric dipole moments of azobenzene groups toward its direction. The observed changes are shown in Fig. 3, where the experimental dependences of the kinetics of light intensity changes from $I_{0}$ to $I_{E}$ are displayed.

The illumination of the polymers with polarized light from the absorption range of the trans-isomers of the azobenzene chromophores results in a transformation of these trans-states into the cis-states. This is a cause for the appearance of the photoinduced optical anisotropy in the polymers. The experimental spectral dependences of $\sigma I_{E}$ after quite a long illumination of the samples with polarized light with $\lambda<550$ $\mathrm{nm}$ are shown in Fig. $2(\theta=\pi / 2)$.

The electric field influence is more essential for P1 and $\mathrm{P} 3$ samples as compared to $\mathrm{P} 2$, and the $\sigma I_{E}$ value increases in samples P1-P3-P2. Comparing the dependences shown in Figs. 2, and 3, one can conclude that, after the long illumination of the samples with linearly polarized light, the field influence on the light transmission gains strength within the long-wave absorption spectra of polymers.

In the investigated polymer samples, the photoinduced optical anisotropy arises as a result of the illumination with a linearly polarized light. Trans-cis isomerization of the azobenzene chromophore groups happens under such light influence. An external electric field has the orienting effect on the photoinduced dipole moments of these groups. This effect reveals itself in the appearance of the electro-optical effect over the range of light wavelengths corresponding to the long-wave edge of the absorption spectra of polymers. In films P1-P3, an external electric field provokes the alignment of the photoinduced dipoles along the force lines of the field. As a result, the interaction between polarized light and these dipoles is weaker, and $\delta I_{E}<0$ for $\theta=\pi / 2$. In films P1 and P3 in the external electric field, polarized light undergoes the more intense dispersion and depolarization, as well as the interaction of azochromophore dipoles with the field resulting in a higher negative value of $\delta I_{E}$. This peculiarity is probably caused by the increased dipole moment of the azobenzene chromophore in the P1-
P3-P2 series and the rotation effect of this dipole moment at the external electric field strengthening.

\section{Conclusions}

From the results obtained and presented here, one can conclude that the thin films of azobenzene polymers can be considered as attractive for the applications requiring a sensitivity to external electromagnetic stimuli such as, e.g., electro-optic light intensity modulators for the optical signal transmission, as well as the polarization holography. In these media, the influence of a DC external electric field on the light transmission is attributed to a displacement of the azobenzene groups from their equilibrium state under its action. The presence of the electron donating and electron accepting groups leads to an increase of the dipole moment of azobenzene chromophore. It results in a larger energy of interaction with the applied electric field and the inreased rotational mobility of the azobenzene dipole moment. The present results show that CT azobenzenes can be of interest for the development of information media.

1. D. Eaton. Nonlinear optical materials. Science 253, 281 (1991).

2. D.M. Burland, R.D. Miller, C.A. Walsh. Second-order nonlinearity in poled-polymer systems. Chem. Rev. 94, 31 (1994).

3. V. Figà, H. Usta, R. Macaluso, U. Salzner, M. Ozdemir, B. Kulyk, O. Krupka, M. Bruno. Electrochemical polymerization of ambipolar carbonyl-functionalized indenofluorene with memristive properties. Optical Materials 94, 187 (2019).

4. V. Figà, J. Luc, M. Baitoul, B. Sahraoui. NLO properties of polythiophenes galvanostatically electrodeposited on ITO glasses. J. Optoelectron. Adv. Mater. 10, 2123 (2008).

5. B. Derkowska-Zielinska, K. Matczyszyn, M. Dudek, M. Samoc, R. Czaplicki, A. Kaczmarek-Kedziera, V. Smokal, A. Biitseva, O. Krupka. All-optical poling and two-photon absorption in heterocyclic Azo dyes with different side groups. J. Phys. Chem. C 123,725 (2019).

6. V. Smokal, A. Krupka, O. Kharchenko, O. Krupka, B. Derkowska-Zielinska, A. Kolendo. Synthesis and photophysical properties of new styrylquinoline-containing polymers. Molec. Cryst. Liq. Cryst. 661, 38 (2018).

7. B. Derkowska-Zielinska, L. Skowronski, T. Kozlowski, V. Smokal, A. Kysil, A. Biitseva, O. Krupka. Influence of peripheral substituents on the optical properties of heterocyclic azo dyes. Optical Materials 49, 325 (2015).

8. B. Derkowska-Zielinska, O. Krupka, V. Smokal, A. Grabowski, M. Naparty, L. Skowronski. Optical properties of disperse dyes doped poly(methyl methacrylate). Molec. Cryst. Liq. Cryst. 639, 87 (2016). 
9. K. Fedus, V. Smokal, O. Krupka, G. Boudebs. Synthesis and non-resonant nonlinear optical properties of pushpull side-chain azobenzene polymers. J. Nonlin. Opt. Phys. Mater. 20, 1 (2011).

10. Z. Sekkat, W. Knoll. Photoreactive Organic Thin Films (Academic Press, 2002) [ISBN: 9780126354904].

11. J.F. Rabek. Photochemistry and Photophysics (CRC Press, 1989) [ISBN: 9780849340420].

12. D.S. Correa, M.R. Cardoso, V.C. Gonçalves, D.T. Balogh, L. De Boni, C.R. Mendonça. Optical birefringence induced by two-photon absorption in polythiophene bearing an azochromophore. Polymer 49, 1562 (2008).

13. C. Fiorini, J.M. Nunzi, F. Charra, M. Lequan, R.M. Lequan, K. Chane-Ching. Light-induced orientation of a low absorbing phosphine oxide azo-dye/PMMA copolymer: Towards a trade-off between transperancy and photoinduced non-linearity. Chem. Phys. Lett. 271 (4-6), 335 (1997).

14. I. Rau, R. Czaplicki, B. Derkowska, J.G. Grote, F. Kajzar, O. Krupka, B. Sahraoui. Nonlinear optical properties of functionalized DNA-CTMA complexes. Nonlinear Optics Quantum Optics 42 (3), 283 (2011).

15. D. Gindre, A. Boeglin, A. Fort, L. Mager, K. D. Dorkenoo. Rewritable optical data storage in azobenzene copolymers. Opt. Express 14, 9896 (2006).

16. B. Kulyk, D. Guichaoua, A. Ayadi, A. El-Ghayoury, B. Sahraoui, Functionalized azo-based iminopyridine rhenium complexes for nonlinear optical performance. Dyes and Pigments 145, 256 (2017).
17. H. El Ouazzani, K., Iliopoulos, M. Pranaitis, O. Krupka, V. Smokal, A. Kolendo, B. Sahraoui. Second- and thirdorder nonlinearities of novel push-pull azobenzene polymers. J. Phys. Chem. B 115 (9), 1944 (2011).

18. N. Davidenko, V. Pavlov, N. Chuprina, I. Davidenko, L. Baath. Thermal influence on passing of polarized light through the $\mathrm{SnO}_{2}: \mathrm{In}_{2} \mathrm{O}_{3} \mathrm{SnO}_{2}: \mathrm{In}_{2} \mathrm{O}_{3}$ layers. J. Appl. Phys. 100, 023111 (2006).

19. M.S. Ho, A. Natansohn, P. Rochon. Azo polymers for reversible optical storage. 7 . The effect of the size of the photochromic groups. Macromolecules 28, 6124 (1995).

Received 24.03.20

В. Смокал, О. Харченко, О. Крупка,

C. Студзинсъкий, М. Давиденко, В. Фіга

ЗМІНИ ОПТИЧНИХ ВЛАСТИВОСТЕЙ АЗОПОЛІМЕРІВ В ЕЛЕКТРИЧНОМУ ПОЛІ

$\mathrm{P}$ е $з$ ю м е

В роботі розглянуто попередні результати, отримані для полімерів з азобензольним фрагментом, що проявляють оптичну активність. Зміни в спектрі поглинання тонкої плівки, що мають реверсивний характер, спостерігаються при освітленні її монохроматичним лінійно поляризованим світлом, під дією прикладеного зовнішнього поля постійного струму. Величина зміни залежить від кута між площиною поляризації світла та напрямком електричного поля постійного струму. 